\title{
Effect of reduction mammoplasty on the pulmonary function tests
}

\author{
Erhan UĞURLU ${ }^{1}$ \\ Adem TOPKARA $^{2}$ \\ Adem ÖZKAN ${ }^{2}$ \\ Ramazan Hakan ÖZCAN ${ }^{2}$ \\ ilknur CAN ${ }^{1}$ \\ Göksel ALTINIŞIK ${ }^{1}$
}

${ }^{1}$ Department of Chest Diseases, Faculty of Medicine, Pamukkale University, Denizli, Turkey

${ }^{1}$ Pamukkale Üniversitesi Tıp Fakültesi, Göğüs Hastalıkları Anabilim Dalı, Denizli, Türkiye

${ }^{2}$ Department of Plastic, Reconstructive and Aesthetic Surgery, Faculty of Medicine, Pamukkale University, Denizli, Turkey

2 Pamukkale Üniversitesi Tıp Fakültesi, Plastik, Rekonstrüktif ve Estetik Cerrahi Anabilim Dalı, Denizli, Türkiye

\section{SUMMARY}

Effect of reduction mammoplasty on the pulmonary function tests

Introduction: Bilateral breast reduction surgery is the surgical treatment of bilateral breast hypertrophy. This is one of the most common breast surgery requested by women, and performed by plastic surgeons. The reasons that patients want this surgery are to re-size sagging breasts aesthetically, and to get rid of somatic symptoms such as shoulder, chest, back, and neck pain. We believe that the objective positive effects of breast reduction surgery exist beside aesthetic. In our study, our aim is to elicit positive effects of surgery on lungs, if there are, by making pulmonary function test and carbon monoxide diffusion test before surgery and after 6 months of surgery.

Materials and Methods: Thirty patients agreed to participate in the study. Study is completed with 19 patients. Pulmonary function test and carbon monoxide diffusion test were made to all patients in preoperative and 6 months of postoperative period. Lung roentgenogram of all patients was performed and height, weight, body mass index were measured. Saturation level was measured.

Results: There was a meaningful increase in FEV ${ }_{1}$ and FVC values in the postoperative period in comparison with pulmonary function test performed in preoperative period. DLCO in postoperative period decreased meaningfully as compared to the preoperative period.

Conclusion: Breast reduction surgery seems to have positive effects on pulmonary function test values and relaxes patients clinically. Patients with big breasts should be evaluated from this perspective if they apply chest diseases clinic with shortness of breath.

Key words: Mammoplasty, respiratory function tests, surgery, lung

\section{ÖZET}

Meme küçültme cerrahisinin solunum fonksiyon testleri üzerine etkisi

Giriş: Bilateral meme küçültme cerrahisi, bilateral meme hipertrofisinin cerrahi tedavisidir. Kadınlar tarafından istenen, plastik cerrahlar tarafinca en yaygın yapılan meme operasyonlarından birisidir. Hastaların bu ameliyatı isteme

\section{Yazışma Adresi (Address for Correspondence)}

\section{Dr. Erhan UĞURLU}

Pamukkale Üniversitesi Tıp Fakültesi, Gögüs Hastalıkları Anabilim Dalı, DENiZLi - TURKEY

e-mail: drerhanugurlu@gmail.com 
nedenleri; sarkan göğüslerini estetik açıdan düzeltmek, göğüs, sırt, omuz ve boyun ağrıları gibi somatik semptomlardan kurtulmaktır. Meme küçültme cerrahisinin estetik dışında objektif olumlu etkileri olduğunu düşünmekteyiz. Çalışmamızda meme küçültme cerrahisi olacak hastalara operasyon öncesi ve operasyondan altı ay sonrasında solunum fonksiyon testi (SFT) ve daha önce hiçbir çalışmada yapılmamış olan karbonmonoksit difüzyon testi yaparak, bu cerrahinin akciğer üzerine varsa olumlu etkilerini ortaya çıkarmayı amaçladık.

Materyal ve Metod: Otuz hasta çalışmamıza katılmayı kabul etti. On dokuz hasta ile çalışma tamamlandı. Hastaların hepsine preoperatif dönemde ve postoperatif dönem altıncı ayda SFT ve karbonmonoksit difüzyon testi yapıldı. Hastaların hepsinin akciğer röntgenogramı çekildi ve boy, kilo, vücut kitle indeksi $\left(\mathrm{kg} / \mathrm{m}^{2}\right)$ ölçüldü. Parmaktan satürasyon ölçen cihaz ile satürasyonları ölçüldü.

Bulgular: Postoperatif dönemde uygulanan solunum fonksiyon testleri preoperatif dönemde uygulananlar ile karşılaştırıldığında FEV ve FVC'de anlamlı derecede artış bulunmuştur. DLCO ise postoperatif dönemde preoperatif döneme göre anlamlı derecede azalmıştır.

Sonuç: Meme küçültme cerrahisinin, hastaları klinik olarak rahatlatan ve solunum fonksiyon testi değerleri üzerine olumlu etkileri var gibi gözükmektedir. Gögüs hastalıkları polikliniğine nefes darlığı ile başvuran büyük memeli hastalar bu açıdan değerlendirilmelidir.

Anahtar kelimeler: Mamoplasti, solunum fonksiyon testleri, cerrahi, akciğer

\section{INTRODUCTION}

Bilateral breast reduction surgery is the surgical treatment of bilateral breast hypertrophy. This is one of the most common breast surgery requested by women, and performed by plastic surgeons (1). The reasons that patients want this surgery are to re-size sagging breasts aesthetically, and to get rid of somatic symptoms such as shoulder, chest, back, and neck pain (2). Although less common than other symptoms of women with bilateral breast hypertrophy, another important symptom is shortness of breath. The weight on thorax reduces compliance of the chest wall and improves breathing (3).

Studies indicate that there is an increase in quality of life and a decrease in symptoms on patients who underwent breast reduction surgery but they are more subjective (survey that asking patients somatic symptoms) and misleading to aesthetic sides of breast reduction surgery (4). Pulmonary function tests in patients who underwent breast reduction surgery are done but objective data can be barely reached on studies $(1,2,5)$.

We believe that the objective positive effects of breast reduction surgery exist beside aesthetic. In our study, our aim is to elicit positive effects of surgery on lungs, if there are, by making pulmonary function test and carbon monoxide diffusion test (which is not performed in any study yet) before surgery and after 6 months of surgery.

\section{MATERIALS and METHODS}

\section{Study Population}

All the volunteers gave an informed consent. Ethical approval was obtained from Ethical Board on Human
Experiments, with the approval number 60116787020/57035. Thirty patients agreed to participate in the study. The patients with any prior lung disease (chronic obstructive pulmonary disease, bronchiectasis, bronchial asthma, interstitial lung disease, etc.), or who were operated from the lungs or chest wall, or with chest wall deformities, smoked, smokers or who quit currently, and with respiratory tract infection recently or currently or in postoperative period were excluded from the study. Four patients with bronchial asthma, 4 patients due to smoking, 2 patients for not coming to postoperative follow-up and 1 patient who had lower respiratory tract infection in postoperative period were excluded from the study. Study is completed with 19 patients.

\section{Methods}

Reduction mammoplasty surgeons used the superomedial pedicle technique in 8 cases $(42 \%)$, the free nipple technique in 6 cases $(32 \%)$, and the inferior pedicle technique in 5 cases $(26 \%)$ (Figure $1,2)$. The amount of breast tissue removed from all patients was recorded.

Pulmonary function test and carbon monoxide diffusion test were made to all patients in preoperative and 6 months of postoperative period. The instrument used (Zan, 300 MGA, Germany) was consistent with American Thoracic Society the criteria. Pulmonary function tests were repeated at least three times and the best values were recorded. Diffusion test was measured with single-breathhold method. All tests were performed by the same technician in the hours of 9 to $12 \mathrm{am}$ for to not be affected by the diurnal rhythm. Pulmonary function test parameters such as forced vital capacity percentage (FVC\%), forced 


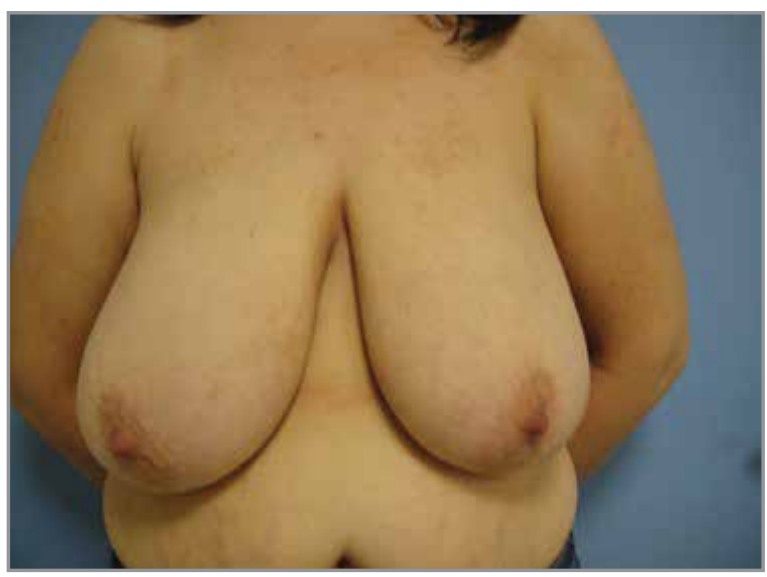

Figure 1. Patient with gigantomastia (preoperative).

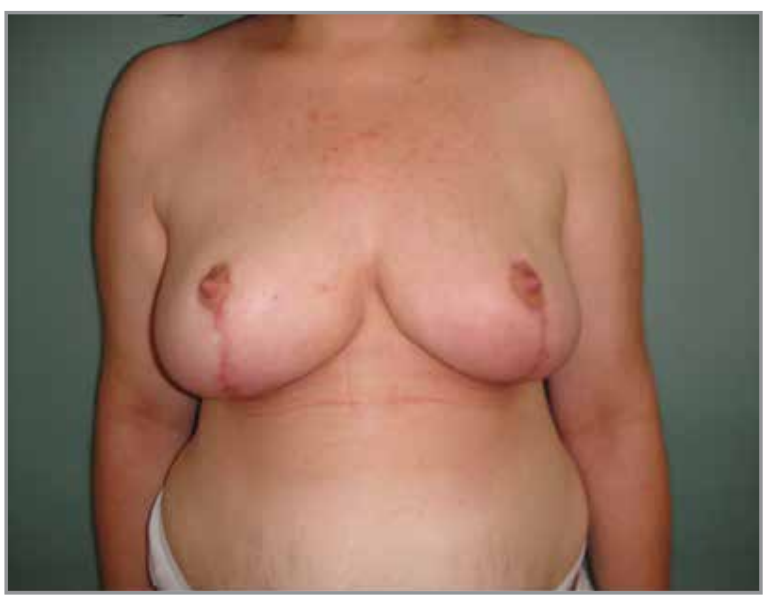

Figure 2. Patient in the postoperative period (six month).

expiratory volume in one second of $\mathrm{FEV} \%\left(\mathrm{FEV}_{1} \%\right)$, the ratio of $\mathrm{FEV}_{1}$ to $\mathrm{FVC}\left(\mathrm{FEV}_{1} / \mathrm{FVC}\right)$, peak expiratory flow rates percentage (PEF\%), forced expiratory flow $25-75 \%$ (FEF25-75\%), total lung capacity (TLC), residual volume (RV) and diffusing capacity of the lungs for the carbon monoxide (DLCO) were measured. Lung roentgenogram of all patients was performed and height, weight, body mass index (weight/height $\left.{ }^{2}\right)\left(\mathrm{kg} / \mathrm{m}^{2}\right)$ were measured. Saturation level was measured with the help of saturation measuring device applied to patients' finger in the preoperative and postoperative period.

\section{Statistical Analysis}

Data was analyzed by the program named by Statistical Package for Social Science (SPSS 17.0.1 for Windows; SPSS Inc, Chicago, IL, 2001). Continuous variables are expressed as mean \pm standard deviation and median (minimum-maximum values). Compliance of the normal distribution for continuous variables was analyzed with the Kolmogorov-Smirnov test. Differences between preoperative and postoperative measurements were evaluated with significance test of difference between two pairs (paired samples t-test) on the provision of parametric test assumptions.

\section{RESULTS}

The mean body mass index and age of patients are shown in Table 1.

Patients' average values, which are $\mathrm{FEV}_{1}, \mathrm{FVC}$, ratio $\left(\mathrm{FEV}_{1} / \mathrm{FVC}\right), \mathrm{PEF}, \mathrm{FEF} 25-75, \mathrm{DLCO}, \mathrm{TLC}$, and RV, were compared in preoperative and postoperative periods (Table 2). While meaningful increase in $\mathrm{FEV}_{1}$ and FVC values was detected in postoperative period, there was a meaningful decrease in the value of DLCO. There was no meaningful difference in the values, which are ratio $\left(\mathrm{FEV}_{1} / \mathrm{FVC}\right), \mathrm{PEF}, \mathrm{FEF} 25-75$, TLC, and RV, obtained in preoperative and postoperative period. Also, meaningful difference was not detected in the saturation values.

\section{DISCUSSION}

The women that underwent breast reduction surgery are satisfied with acquiring that surgical treatment and reduced neck, shoulder, and back pain was presented (6-10). This surgery is indicated that have several positive effects in studies conducted in recent years $(11,12)$. All of these studies are subjective and based on a survey. Due to the fact that all of our patients were completed our study and underwent the surgery, they stated their satisfaction and having a serious reduction in their complaints.

In our study, there was a meaningful increase in $\mathrm{FEV}_{1}$ and FVC values in the postoperative period in comparison with pulmonary function test performed in preoperative period. This situation can be explained

Table 1. Mean of age, body mass index, and amount of
removed tissue
\begin{tabular}{|lcc|}
\hline & $\begin{array}{c}\text { Mean } \pm \text { Std } \\
\text { deviation }\end{array}$ & $\begin{array}{c}\text { Median } \\
\text { (min-max) }\end{array}$ \\
\hline Age (years) & $45.42 \pm 12.32$ & $48(19-70)$ \\
BMI $\left(\mathrm{kg} / \mathrm{m}^{2}\right)$ & $33.67 \pm 4.10$ & $33(29.1-46)$ \\
$\begin{array}{l}\text { Amount of removed } \\
\text { tissue (g) }\end{array}$ & $2190 \pm 844$ & $2060(830-3460)$ \\
\hline BMl: Body mass index. & & \\
\hline
\end{tabular}


Uğurlu E, Topkara A, Özkan A, Özcan RH, Can I, Altınışık G.

Table 2. Pulmonary function and diffusion test in preoperative and postoperative period

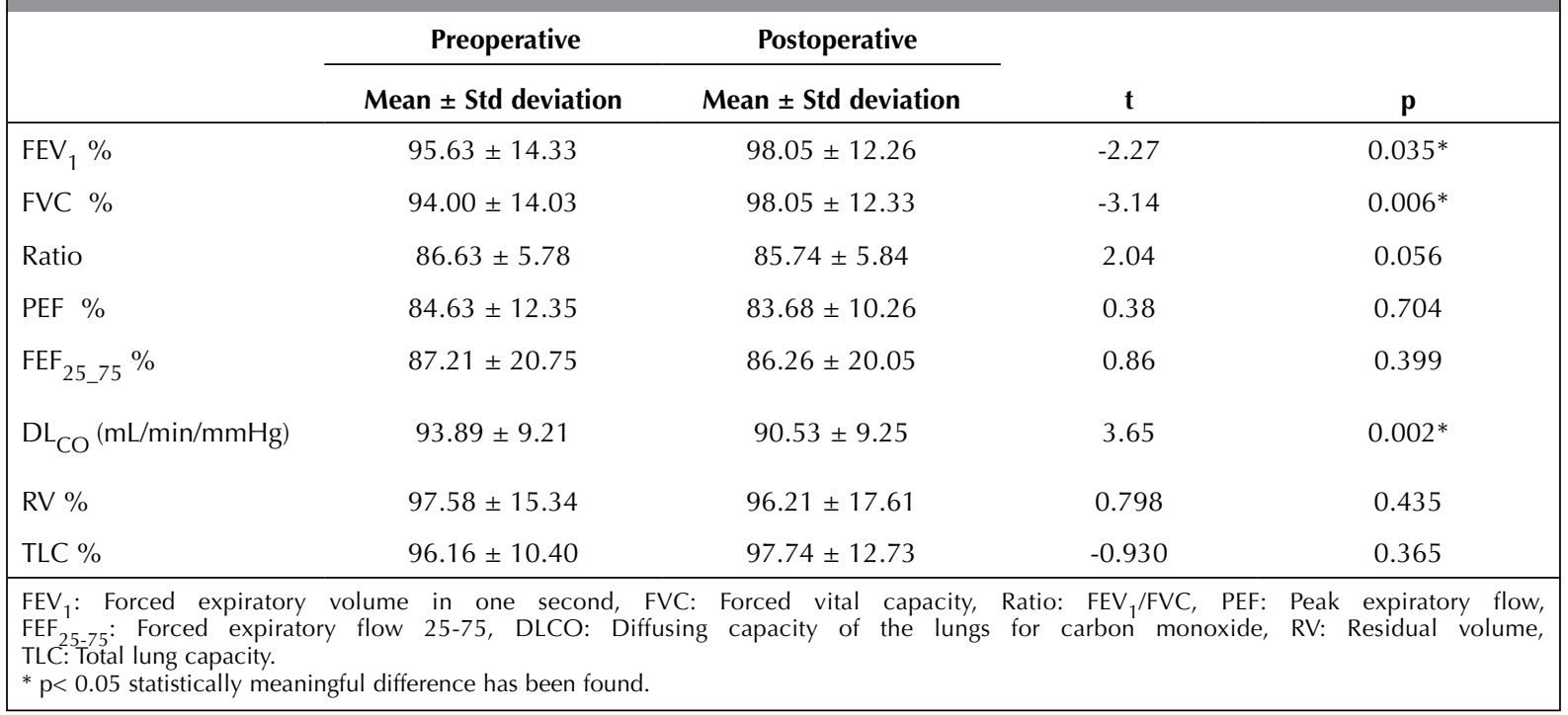

by relaxation in breathing as a result of increased chest wall compliance with breast reduction.

Goldwyn did not find a meaningful difference between preoperative and postoperative pulmonary function test in his study performed with 10 patients that underwent breast reduction surgery (13). Starly et al. found significant improvement in the values of PEF and peak inspiratory flows (PIF) in their study with 19 patients (5). Sood et al. found significant improvement in inspiratory capacity, PEF and maximal voluntary ventilation value in their study of 43 patients (2). Iwuagwu et al. found significant improvement of FVC value in the intervention group in their randomized controlled study with 73 patients (1). Cunha et al. found a significant improvement in TLC and RV values in their study with participation of 12 patients (4). Kececi et al. also found a significant improvement in FVC value in their study with participation of 31 patients (14). Ceber et al. found a significant improvement in $\mathrm{FEV}_{1}, \mathrm{FVC}$, and FEF25-75 values in their study of 30 patients (15). The results in our study are similar to the results obtained in the study made by Ceber et al. and Kececi et al.

Decrease in chest wall compliance results in a decrease in FVC and FEV 1 values (16). Reduction mammaplasty has been shown to increase in chest wall compliance (17). It is already supported by this theory that morbid obesity reduces chest wall compliance (18). This can be explained by the increase in FVC and $\mathrm{FEV}_{1}$ after reduction mammaplasty in our patients.
DLCO is a clinically and commonly useful test which provides a measure of the transfer of gas in the lungs quantitatively (19). It provides essential information about pulmonary microcirculation (19). In our study, DLCO in postoperative period decreased meaningfully as compared to the preoperative period. This situation can be explained by the decrease in DLCO as a result of a decrease in thoracic blood volume with decrease venous return associated with increased transpulmonary pressure due to increase in chest wall compliance together with the breast reduction $(20,21)$. On the other hand, the increase in chest wall compliance increases lung capacities and facilitates ventilation together. Therefore, an increase in diffusion can be expected. As far as we know, there is no other study looking at diffusion capacity before and after reduction mammaplasty. More study is needed to clarify this issue.

The greatest limitation of our study is the small number of patients due to the fact that patients remained out of study for several reasons. The arterial blood gas could not be performed due to refusing issue of patients particularly in postoperative period because the arterial blood gas is an invasive procedure despite being a more objective parameter. This is another limitation of our study.

The results of the studies made so far demonstrate that breast reduction surgery shows positive effects on pulmonary function test; however, effects on what parameters is still controversial. 
As a consequence, breast reduction surgery seems to have positive effects on pulmonary function test values and relaxes patients clinically. Patients with big breasts should be evaluated from this perspective if they apply chest diseases clinic with shortness of breath.

\section{REFERENCES}

1. Iwuagwu OC, Platt AJ, Stanley PW, Hart NB, Drew PJ. Does reduction mammaplasty improve lung function test in women with macromastia? Results of a randomized controlled trial. Plast Reconstr Surg 2006;118:1-6.

2. Sood R, Mount DL, Coleman JJ,Ranieri J, Sauter S, Mathur $P$, et al. Effects of reduction mammoplasty on pulmonary function and symptoms of macromastia. Plast Reconstr Surg 2003; 111:688-94.

3. Elhusseiny A, Elshahat A, Wagih K, Hanafy AA, Mahmoud AS. Relation between reduction mammaplasty and pulmonary functions. Ann Plast Surg 2013;70:271-5.

4. Cunha MS, Santos LL, Viana AA, Bandeira NG, Filho JA, Meneses $J V$. Evaluation of pulmonary function in patients submitted to reduction mammaplasty. Rev Col Bras Cir $2011 ; 38: 11-4$.

5. Starley IF, Bryden DC, Tagari S, Mohammed P, Jones BP. An investigation into changes in lung function and the subjective medical benefits from breast reduction surgery. Br J Plast Surg 1998;51:531-4.

6. Stroembeck JO. Macromastia in women and its surgical treatment. A clinical study based on 1,042 cases. Acta Chir Scand Suppl 1964;341:1.

7. Pers M, Nielsen IM, Gerner N. Results following reduction mammaplasty as evaluated by the patients. Ann Plast Surg 1986;17:449-55.

8. Serletti JM, Reading G, Caldwell E, Wray RC. Long-term patient satisfaction following reduction mammoplasty. Ann Plast Surg 1992;28:363-5.

9. Gonzalez F, Walton RL, Shafer B, Matory WE Jr, Borah GL. Reduction mammaplasty improves symptoms of macromastia. Plast Reconstr Surg 1993;91:1270-6.
10. Miller AP, Zacher JB, Berggren RB, Falcone RE, Monk J. Breast reduction for symptomatic macromastia: can objective predictors for operative success be identified? Plast Reconstr Surg 1995; 95:77-83.

11. Gonzalez MA, Glickman LT, Aladegbami B, Simpson $R$. Quality of life after breast reduction surgery: a 10-year retrospective analysis using the Breast $Q$ questionnaire: does breast size matter? Ann Plast Surg 2012;69:361-3.

12. Valtonen JP, Setälä $L P$, Mustonen $P K$, Blom M. Can the efficacy of reduction mammoplasty be predicted? The applicability and predictive value of breast-related symptoms questionnaire in measuring breast-related symptoms pre- and postoperatively. I Plast Reconstr Aesthet Surg 2014;67:676-81.

13. Goldwyn RM. Pulmonary function and bilateral reduction mammoplasty. Plast Reconstr Surg 1974;53:84.

14. Kececi $Y$, Dagistan S. Effects of breast reduction on pulmonary function. Int Surg 2014;99:300-4.

15. Ceber M, Yuksek A, Mutlu LC, Bali I, Topcu B. Reduction mammaplasty effect on pulmonary function and arterial blood gas in the over weight female. Aesthetic Plast Surg 2015;39:540-6.

16. Lalley $P M$. The aging respiratory system--pulmonary structure, function and neural control, Respir Physiol Neurobiol 2013;187:199-210.

17. Izadpanah A, Karunanayake M, Bracco D, Luc M. Effect of reduction mammoplasty on chest wall compliance. Eur I Plast Surg DOI:10.1007/s00238-012-0758-3.

18. Rasslan Z, Junior RS, Stirbulov R, Fabbri RMA, Lima CAC. Evaluation of pulmonary function in class I and II obesity. J Bras Pneumol 2004; 30:508-14.

19. Hegewald MJ. Diffusing capacity. Clin Rev Allergy Immunol 2009;37:159-66.

20. Bartu Saryal S. Solunum mekaniği. Solunum 2000;2:11225.

21. Smith TC, Rankin J. Pulmonary diffusing capacity and the capillary bed during Valsalva and Müller maneuvers. I Appl Physiol 1969;27:826-33. 